Fani Sakellariadou*, Francisco J. Gonzalez, James R. Hein, Blanca Rincón-Tomás, Nikolaos Arvanitidis and Thomas Kuhn

\title{
Seabed mining and blue growth: exploring the potential of marine mineral deposits as a sustainable source of rare earth elements (MaREEs) (IUPAC Technical Report)
}

https://doi.org/10.1515/pac-2021-0325

Received March 30, 2021; accepted October 19, 2021

\begin{abstract}
The expected growth of the global economy and the projected rise in world population call for a greatly increased supply of materials critical for implementing clean technologies, such as rare earth elements (REEs) and other rare metals. Because the demand for critical metals is increasing and land-based mineral deposits are being depleted, seafloor resources are seen as the next frontier for mineral exploration and extraction. Marine mineral deposits with a great resource potential for transition, rare, and critical metals include mainly deep-sea mineral deposits, such as polymetallic sulfides, polymetallic nodules, cobalt-rich crusts, phosphorites, and rare earth element-rich muds. Major areas with economic interest for seabed mineral exploration and mining are the following: nodules in the Penrhyn Basin-Cook Islands Exclusive Economic Zone (EEZ), the Clarion-Clipperton nodule Zone, Peru Basin nodules, and the Central Indian Ocean Basin; seafloor massive sulfide deposits in the exclusive economic zones of Papua New Guinea, Japan, and New Zealand as well as the Mid-Atlantic Ridge and the three Indian Ocean spreading ridges; cobalt-rich crusts in the Pacific Prime Crust Zone and the Canary Islands Seamounts and the Rio Grande Rise in the Atlantic Ocean; and the rare earth element-rich deep-sea muds around Minamitorishima Island in the equatorial North Pacific. In addition, zones for marine phosphorites exploration are located in Chatham Rise, offshore Baja California, and on the shelf off Namibia. Moreover, shallow-water resources, like placer deposits, represent another marine source for many critical minerals, metals, and gems. The main concerns of deep-sea mining are related to its environmental impacts. Ecological impacts of rare earth element mining on deep-sea ecosystems are still poorly evaluated. Furthermore, marine mining may cause conflicts with various stakeholders such as fisheries, communications cable owners, offshore wind farms, and tourism. The global ocean is an immense source of food, energy, raw materials, clean water, and ecosystem services and suffers seriously by multiple stressors from anthropogenic sources. The development of a blue economy strategy needs a better knowledge of the environmental impacts. By protecting vulnerable areas, applying new technologies for deep-sea mineral exploration and mining, marine spatial planning, and a regulatory framework for minerals extraction, we may achieve sustainable management and use of our oceans.
\end{abstract}

Article note: Sponsoring body: IUPAC Chemistry and the Environment Division. See more details on page 348. This manuscript was prepared in the framework of IUPAC project 2018-039-3-600.

*Corresponding author: Fani Sakellariadou, Lab. of Geochemical Oceanography, Department of Maritime Studies, University of Piraeus, Piraeus, Greece, e-mail: fsakelar@unipi.gr

Francisco J. Gonzalez, Marine Geology Division, Geological Survey of Spain, Madrid, Spain

James R. Hein, United States Geological Survey, Pacific Coastal and Marine Science Center, Santa Cruz, CA, USA

Blanca Rincón-Tomás, Institute for General Microbiology, Christian-Albrechts-University Kiel, Kiel, Germany

Nikolaos Arvanitidis, Department of Mineral Resources, Geological Survey of Sweden, Upsala, Sweden

Thomas Kuhn, Federal Institute for Geosciences and Natural Resources, Hannover, Germany 
Keywords: Deep-sea ecosystems; environmental impacts; ferromanganese crusts; IUPAC chemistry and the environment division; polymetallic nodules; polymetallic sulfides; rare earth elements; seabed mining.

\section{CONTENTS}



2 Major REE mineral deposit types …................................................................................................331

3 Global REE market and resource potential ................................................................................... 332

4 REE exploration and exploitation potential of seabed mineral deposits ................................... 333

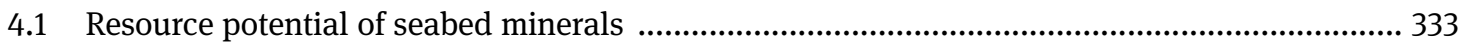

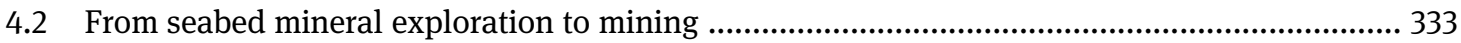

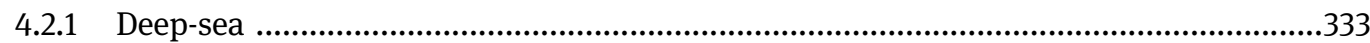

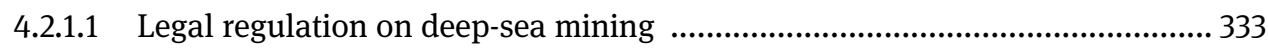

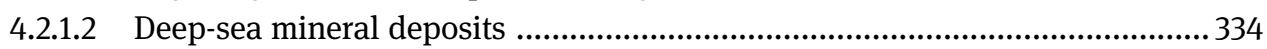



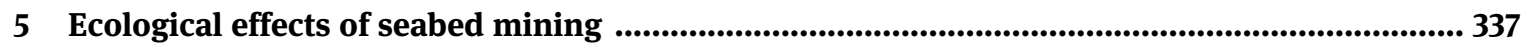

5.1 Prospective mining areas with REE as a potential byproduct and their related ecosystems ...... 338

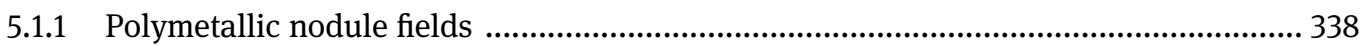

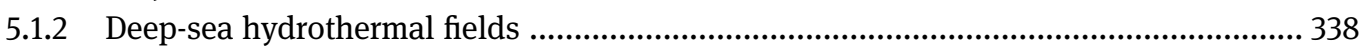

5.1.3 Cobalt-rich ferro-manganese crusts on seamounts ......................................................... 339

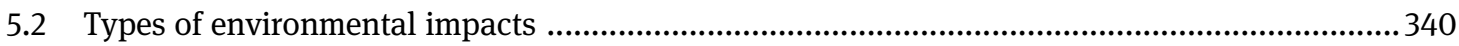



5.2.2 Sediment disturbance and plume discharges ................................................................. 340



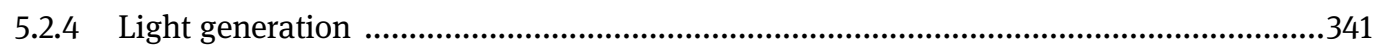

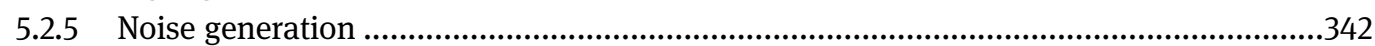

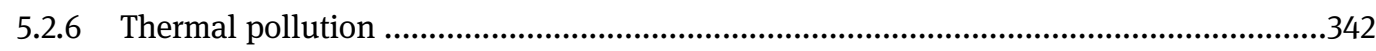

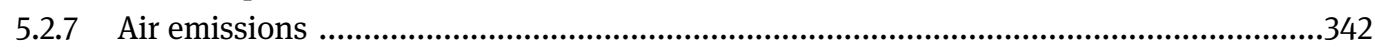

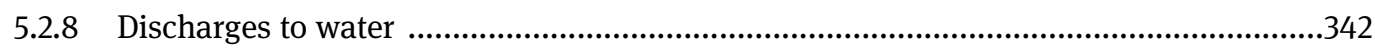

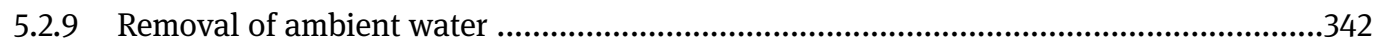

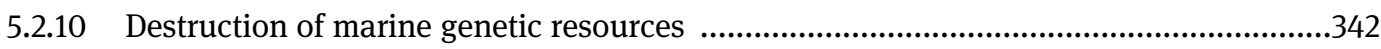

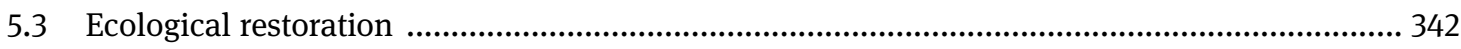

6 In search of sustainable exploitation of seabed mineral deposits containing REEs .................. 343

7 Socio-economic impacts of deep-sea mining ......................................................................................343

8 Marine resource mining versus land-based mining for REEs …..............................................344



10 Exploration-exploitation versus preservation of the global ocean .......................................346





List of acronyms ...........................................................................................................................................348

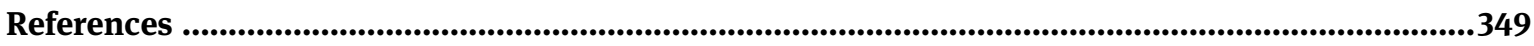

Relevant-related projects ............................................................................................................................................351

\section{Introduction}

The world economy is predicted to grow at an average of just over $3 \%$ per annum in the period 2014 to 2050 and nearly tripling by 2050. The world's population is projected to grow from $7.8 \times 10^{9}$ in 2020 to $9.8 \times 10^{9}$ in 2050 , according to a United Nations report [1]. This growth will require increased food, energy, and raw materials, 
putting pressure on the environment. A more efficient use of resources is needed along with the development of new green technologies to ensure that long-term global growth is environmentally sound.

Rare earth elements (REEs) is the name for a group of 15 lanthanide elements; however, we also include here the chemically similar elements yttrium and scandium in the designation REEs. The REEs are divided into light and heavy. Although relatively abundant in the Earth's crust, economic REE deposits are rather rare. REEs exhibit unique physical, chemical, and light-emitting properties and are very much needed in developing and implementing clean energy technologies. They have multi-functional and industrial uses, such as in highstrength magnets, medical devices, mobile phones, flat-screen TVs, energy-efficient lighting, and superconductors. In 2019, $63 \%$ of the REEs entering the global market were produced in China, with $37 \%$ of the global land-based reserves occurring in China [2]. Demand for these elements is thought to be growing at a rate of approximately 5 to $10 \%$ per year [3, 4], although rapid technological development means that accurate prediction is difficult. Recycling of scrap consumer electronics and technical industrial components will increasingly contribute to REE supply in the future [5] but is unlikely to be able to meet increasing demand [6], and thus, mining of mineral deposits is expected to continue as the major source for REEs well into the future.

Covering about $71 \%$ of the Earth's surface, the oceans represent a potentially promising new frontier for the exploration of mineral resources. The term "strategic and critical metal" refers to metals that are essential to clean energy technologies and sustainable products and manufacturing industries of the $21^{\text {st }}$ century but having a significant risk of supply disruption. Facing the critical raw materials sector, the European Commission has identified security of mineral supply as a priority challenge. The 2020 list of Critical Raw Materials reflects societies' growing demand for an ever-increasing number and quantity of minerals and metals supply that enable the green energy and technology sectors [7]. The global demand for REEs, cobalt, and other rare, critical, and strategic metals, concurrent with the rapidly diminishing quality and quantity of land-based mineral deposits, has situated the seafloor as a promising new frontier for the exploration of mineral resources. However, as the marine environment is already under stress from over-exploitation, pollution, declining biodiversity, and climate change, the use of the untapped potential of the ocean will require responsible and sustainable approaches.

\section{Major REE mineral deposit types}

Existing REE mines and potential future mineral deposits are situated where geological processes concentrated REE grades significantly above their crustal average. REE mineral deposits can be divided into different types based on their geological associations and related REE ore-forming processes. They include deposits formed by high-temperature (magmatic and hydrothermal) processes, typically associated with carbonatites, alkaline igneous rocks, and hydrothermal systems, as well as deposits formed by low-temperature processes (erosion, weathering, and sedimentary transport) such as placers, bauxites, laterites, and ion-adsorption clays (Fig. 1). Primary REE mineral deposits are typically associated with carbonatites and alkaline-peralkaline igneous rocks, from which most of the LREEs are mined. Erosion or weathering of primary types may produce deposits, such as placer and ion adsorption clay deposits, the latter from which many of the HREEs are mined. A short description of REE mineral deposit types is given below.

Carbonatites are currently the main sources of global REE production [9]. The reopened, to some extent, mines at Bayan Obo and Maoniuping in China and Mt Weld in Australia, as well as the recently closed Mountain Pass mine in the USA, are all in fresh or weathered carbonatites.

Alkaline igneous rocks host economically significant mineral resources of REEs. Most exploitable REE mineralizations are associated with peralkaline intrusions [10] and the only active mining takes place in the Lovozero agpaitic nepheline syenite complex, in Russia, where the main REE-bearing ore mineral is loparite $[11,12]$. Deposits in agpaitic nepheline syenites are commonly characterized by low Th and U contents.

Vein and skarn REE deposits are found in systems that do not appear to be intimately associated with alkaline igneous rocks or carbonatites. The most well-known example is the mineral deposits of the Bastnäs 


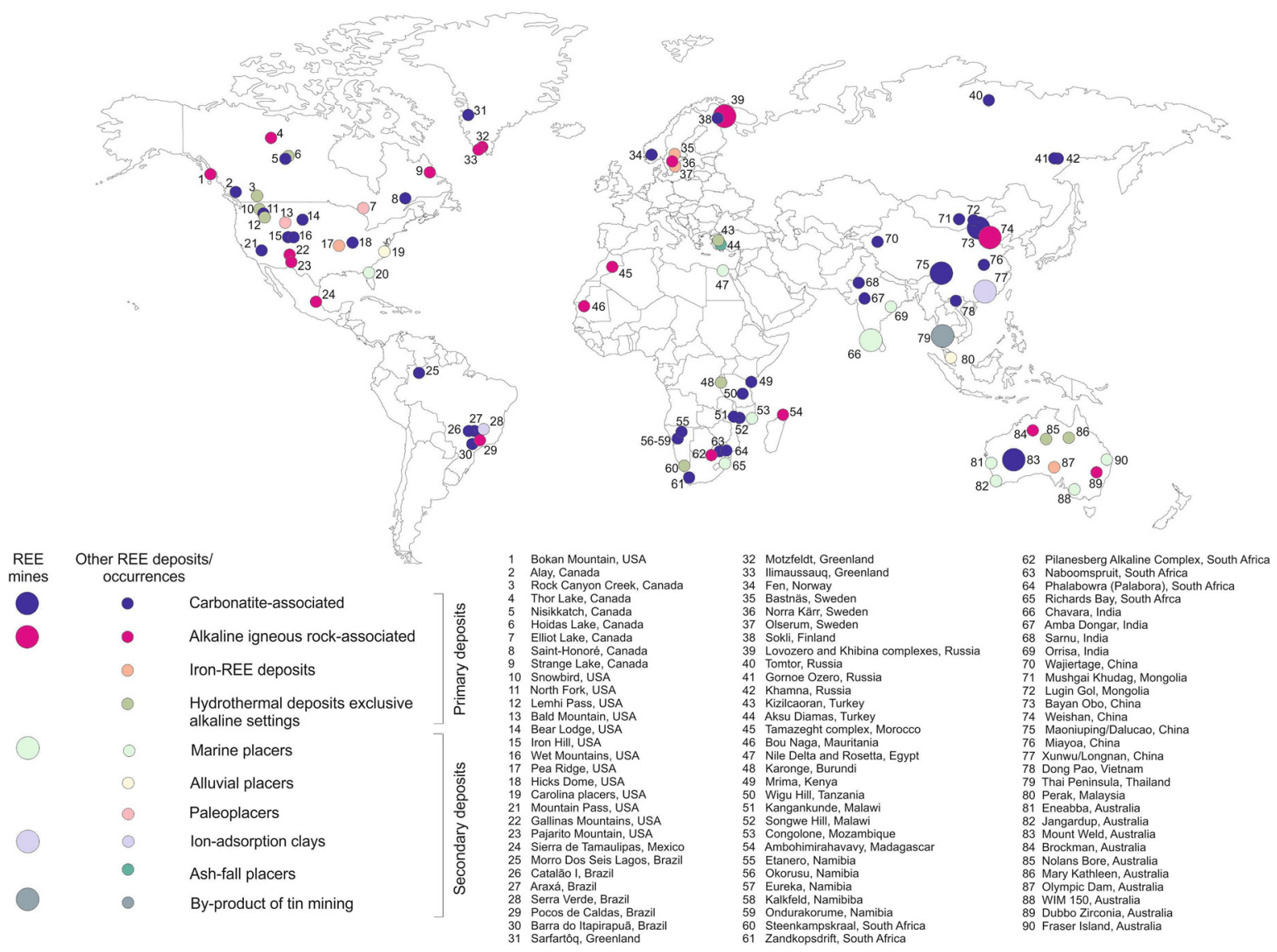

Fig. 1: Map showing the global distribution of REE mineral deposit sites (NERC 2017, [8]).

area in Sweden [13]. Other examples are the deposits at Steenkampskraal in South Africa and Gakara in Burundi.

Placer deposits have been a source of REEs for some time (see Section 4.2.2).

Bauxites are widely mined across the globe for the extraction of aluminum, producing a waste material (red mud) with elevated REE concentrations [14].

Laterites form thick weathering profiles in temperate to tropical zones across the globe. Where such weathering profiles are developed on igneous or meta-igneous rocks, REE can be remobilized into secondary minerals that accumulate at specific layers within the profile [15] and the weathered zones may represent a significant REE resource. A classic example of this is the active mine at Mt Weld in Australia, where weathering of a carbonatite led to the formation of a highly REE-enriched laterite zone up to $70 \mathrm{~m}$ thick, which is now covered by later sediments [16]. This laterite zone contains a wide range of REE-bearing secondary phosphate minerals [17].

The sub-tropical weathering of igneous rocks to form REE-bearing minerals forms ion adsorption clay-type REE deposits. The only currently active REE mining of this type occurs in China. Localities with similar deposits are found in Brazil (Serra Verde project) and Madagascar (Tantalus project) [18].

\section{Global REE market and resource potential}

China controls the global market as a leading producer and user of critical and strategic minerals and metals, including the REE, and is a leading European Union and United States supplier [19]. The US does have a rare 
earth mine in Mountain Pass in California, but the only US processing plant closed in 2015 and the REE ore is nowadays sold to China, where also the processing takes place.

In 2011-2013, Japanese scientists located a seabed REE mineral deposit near Minamitori Island with estimated resources of 1.2 million tonnes of REO (REE oxides). It is low-grade and would not likely be economic to produce it as a single commodity.

The EU countries do not have REE mines [20]. Ongoing exploration projects in Europe are interrupted or slowly progressing, such as Norra Karr in Sweden, Storkwitz in Saxony, Kvanefjeld and Kringlerne in Greenland, Fen in Norway, and Sokli in Finland. The EU still has the remnants of a REE processing and refining capacity at the US-owned Silmet operation in Estonia. Rhodia had a rare earth refining operation at La Rochelle (France), which closed down. The iron ore producer LKAB in Sweden and the fertilizer producer Yara in Norway are currently developing processes to start REE production operations using their apatite-rich byproducts and mining wastes. A potential exists also in coal and aluminum ore mining wastes. One of the issues preventing the start of REE projects in the EU concerns the possible impacts on the environment. The processing and refining require high volumes of toxic chemicals and usually removal of uranium and thorium from the ores, even though not all ores are radioactive.

The total amount of the global REE reserves is approximately $120 \times 10^{6}$ tonnes REO, located in China $\left(44 \times 10^{6}\right.$ tonnes), Brazil $\left(22 \times 10^{6}\right.$ tonnes), Vietnam $\left(22 \times 10^{6}\right.$ tonnes), Russia $\left(12 \times 10^{6}\right.$ tonnes $)$, India (6.9 $\times 10^{6}$ tonnes), Australia (3.3 $\times 10^{6}$ tonnes), Greenland (1.5 $\times 10^{6}$ tonnes), USA $\left(1.4 \times 10^{6}\right.$ tonnes), Tanzania $\left(8.9 \times 10^{5}\right.$ tonnes), Canada $\left(8.3 \times 10^{5}\right.$ tonnes $)$, South Africa $\left(7.9 \times 10^{5}\right.$ tonnes $)$, and $3.1 \times 10^{5}$ tonnes spread in other countries [2].

\section{REE exploration and exploitation potential of seabed mineral deposits}

\subsection{Resource potential of seabed minerals}

Studies dedicated to understanding the genesis, distribution, and resource potential of deep-sea minerals began in the early 1970s [21]. Deep-sea deposits span a large diversity of environments and resource types, including high and low temperature hydrothermal deposits (seafloor massive sulfides, also called polymetallic sulfides), phosphorites, cobalt-rich ferromanganese crusts (also called cobalt-rich crusts), manganese nodules (also called polymetallic nodules), and REE-rich muds. All these deposits are particularly attractive for their polymetallic nature with high contents of transition, rare, and critical elements. Moreover, shallow-water resources, like placer deposits, represent another marine source for many critical metals and gems. The seabed mineral resources host the largest reserves on Earth for some critical metals like cobalt, tellurium, manganese, and the REE, all essential components for industry [21].

\subsection{From seabed mineral exploration to mining}

\subsubsection{Deep-sea}

\subsubsection{Legal regulation on deep-sea mining}

The rapid advances in technology and growth in our understanding of the deep ocean are providing opportunities for the mining of resources on the seabed. This implies an urgency in updating national and international regulations concerning the limits, guidelines, and protocols that must be followed once different public and private identities are positioned to exploit seabed resources, like REE. Furthermore, national and international institutions and exploration contractors are challenged to develop technologies and regulations 
that address irreversible impacts during the search for and sustainable exploitation of deep-sea resources. The key approaches apply the precautionary approach and adaptive management.

The United Nations Convention on the Law of the Sea established the International Seabed Authority (ISA) [22]. This international organization regulates deep-sea exploration and mining of the seabed in areas beyond national jurisdictions. One aim is to prevent, reduce, and control pollution of the marine environment, to protect and conserve the natural resources, and prevent damage to the flora and fauna (that is, the biodiversity) of the marine environment that may arise from mining activities. The ISA is finishing the exploitation regulations that will permit states parties, state enterprises, natural or juridical persons, or consortium of entities to extract minerals for the benefit of humankind as a whole in areas beyond national jurisdictions, the so-called "The Area" (covering around $54 \%$ of the total area of the global ocean). Within the Mining Code, contractors are required to propose the location and size of Preservation Reference Zones and Impact Reference Zones, areas in which no mining takes place and are used for monitoring mining activity, respectively [23].

\subsubsection{Deep-sea mineral deposits}

The first large deep-sea mineral deposit discovery was the extensive polymetallic nodule field, in between the Clarion and Clipperton fracture zones in the 1960s (CCZ [24]). It was followed in the later 1970s by hydrothermal systems and associated metalliferous sediments, sulfide chimneys, and mounds in the Red Sea and SE Pacific Ocean [25-27] and then in the early 1980s by Fe-Mn crusts rich in cobalt on seamounts in the Pacific Ocean [28]. These discoveries were the basis for research and exploratory operations during the last five decades. Recent discoveries of white smokers associated with ultra-mafic-hosted serpentinization (Lost City [29]) and REE-rich muds from the Pacific Ocean [30] have contributed to increase our knowledge on the diversity of mineralization types and the complex interactions between the geosphere, biosphere, and hydrosphere to form this wide array of mineral deposits. Among the deep-sea deposits, the most interesting for their REE concentrations are the ferromanganese crusts, polymetallic nodules, and phosphorites [31, 32]. The mining of nodules was anticipated to begin in the late 1970s to early 1980s but did not occur due to the abrupt fall in the price of base metals in the beginning of the 1980s, causing the closure of many onshore mining operations, and therefore a decrease of interest in the exploitation of marine minerals. In the beginning, the commercial interest was directed to base and noble metals (e.g., $\mathrm{Mn}, \mathrm{Cu}, \mathrm{Zn}, \mathrm{Au}$, and $\mathrm{Ag}$ ). The research that has been conducted in the past decade showed that there are additional rare metals and REE that are potential byproducts of mining of the major metals of interest [21].

In fact, vast areas of the deep seafloor have been contracted for exploration and more contracts are signed almost yearly. In 2000, 2010, and 2012, the Council and Assembly of the ISA passed regulations for the exploration for polymetallic nodules, polymetallic sulfides, and cobalt-rich ferromanganese crusts respectively [23]. Thirty contractors signed 15-year contracts with the ISA for exploration for these three commodities on the deep seabed of the Atlantic, Pacific, and Indian oceans [22]. Over 15 years, these exploration areas will be the subject of relinquishments and will be smaller by the end of the contract (not more than $2500 \mathrm{~km}^{2}$ for polymetallic sulfides, $1000 \mathrm{~km}^{2}$ for cobalt-rich ferromanganese crusts, and $75 \times 10^{3} \mathrm{~km}^{2}$ for polymetallic nodules). Now, various deep-ocean mines are scheduled to start operations within the next years in areas under national jurisdictions in the Red Sea, Southeast Atlantic, and West Pacific Ocean (Fig. 2).

Polymetallic nodules have two genetic endmembers, hydrogenetic nodules where nearly all metals are derived from cold ambient seawater (Penrhyn Basin-Cook Islands EEZ nodules), and diagenetic nodules where nearly all metals are derived from the pore water of sediments (Peru Basin nodules). Nodules that acquire metals from both sources (mixed type) are the most common and include the well-known CCZ nodules [33]. The CCZ nodules are of economic interest primarily for $\mathrm{Ni}, \mathrm{Cu}$, and $\mathrm{Mn}$, and possibly $\mathrm{Co}$, whereas Cook Islands EEZ nodules have the highest Co, REE, and Ti contents, and the Peru Basin nodules the highest Mn and Li contents, with Ni contents equal to those of the CCZ nodules. These three types of nodules occur throughout the global ocean, predominantly on the surface of sediment-covered abyssal plains at 3.5 to $6.5 \mathrm{~km}$ water depth, with low sedimentation rates and below or just above the calcite compensation depth [21, 34]. The three regions mention above and the Central Indian Ocean basin contain the most extensive nodule fields. Other deposits in the Arctic Ocean and different locations in the northeast and southwest Atlantic are as yet poorly explored [21, 35]. 


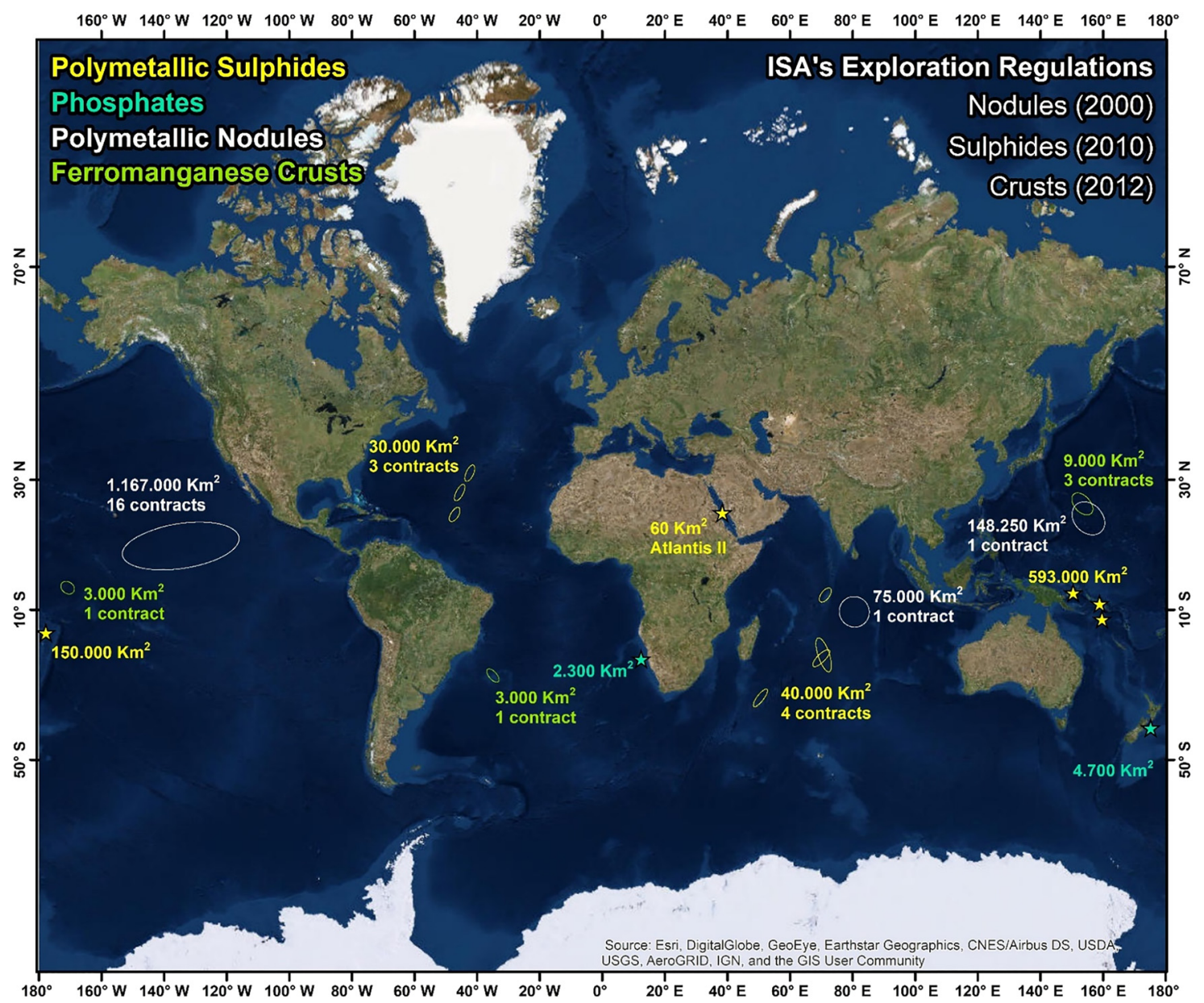

Fig. 2: Global map of seabed minerals exploration. The stars represent areas under national jurisdictions. Modified from [21].

The CCZ and Central Indian basin are the areas of greatest economic interest in international waters. Belgium, China, Cook Islands, France, Germany, India, Japan, Kiribati, South Korea, Nauru, Russia, Singapore, Tonga, the UK, and a group of countries under the name Inter-Ocean Metals (Bulgaria, Cuba, The Czech Republic, Poland, Russia, and the Slovak Republic) through their Federal agencies, have signed exploration contracts with the ISA for polymetallic nodule areas of about $75 \times 10^{3} \mathrm{~km}^{2}$ each [22]. The Cook Islands EEZ within the Penrhyn and Samoa basins, in the central south Pacific, covers $1977 \times 10^{3} \mathrm{~km}^{2}$, with a huge nodule field within which $123.8 \times 10^{3} \mathrm{~km}^{2}$ is estimated to have greater than $25 \mathrm{~kg} / \mathrm{m}^{2}$ nodule abundance, yielding about $3.6 \times 10^{9}$ wet tonnes, with a mean REE concentration of $0.168 \%$. These data indicate that the Cook Islands EEZ is potentially an excellent polymetallic resource [36].

Ferromanganese crusts are shown high interest for their important content of Co and REEs in addition to traditional metals like $\mathrm{Mn}, \mathrm{Ni}$, and Mo. The most interesting areas for exploration and mining occur in seamounts, banks, ridges, and plateaus at water depths from about 1.5 to $2.5 \mathrm{~km}$, especially in the northwest equatorial Pacific, the Prime Crust Zone (PCZ) [21, 37]. The northeast Atlantic margin (e.g., Macaronesia and Iberian continental margins) and Indian oceans are additional potential targets for exploration [21, 35, 38, 39]. Older seamounts (Jurassic and Cretaceous age) from the northwest Pacific PCZ and northwest and northeast Atlantic represent the most significant features to preserve thick and extensive ferromanganese crusts, that also typically have the highest concentrations of REEs [21, 39-41]. Five exploration contracts have been signed with the ISA in international waters from the northwest Pacific Ocean PCZ (four contracts) and southwest Atlantic Ocean (one contract) on Rio Grande Rise [22]. Brazil, China, Japan, Korea, and Russia have sponsored 
contracts with various entities that have been signed with the ISA for cobalt-rich ferromanganese crust exploration areas of about $3 \times 10^{3} \mathrm{~km}^{2}$ each. Exploration is accelerating and new requests for contracts are made regularly.

Marine phosphorites concentrate REEs during their diagenetic formation in a variety of oceanic settings, including lagoon/insular areas, continental margins, and seamounts [32, 42]. Old seamounts (Cretaceous) and continental margin banks, shelves, and plateaus with the presence of upwelling are potential areas for the exploration of phosphorites. The most interesting for their high contents of HREEs (essential for high-tech and green-tech applications) are the seamount phosphorites. They contain a high HREE complement (mean $60 \%$ ) of the total REE. As phosphorites and Fe-Mn crusts often occur in association, as happens in the Pacific and Atlantic oceans [32, 35, 43], seamounts with phosphorite substrates covered by Fe-Mn crusts might be ideal mine locations. Extraction of $\mathrm{P}$ and $\mathrm{Mn}$ as principal ores could provide other potential co-products/byproducts like REEs, Co, Ni, Te, F, and Nb. Miocene through Quaternary phosphorite deposits from the continental shelves and slopes, adjacent to areas of strong upwelling off western South America, Northern Spain, Morocco, Namibia, and South Africa show a high potential for exploration [44]. Three zones have been leased in the global ocean for marine phosphorites exploration. They are Chatham Rise off New Zealand by Chatham Rock Phosphate Ltd (Wellington, New Zealand), offshore Baja California in Mexico by Odyssey Marine Exploration and Exploraciones Oceanicas, and on the shelf off Namibia by Namibian Marine Phosphate Ltd [32]. Phosphorite nodules with an average $\mathrm{P}_{2} \mathrm{O}_{5}$ content of $22 \%$ lie between water depths of 350 to $450 \mathrm{~m}$ on the summit platform of the Chatham Rise, east of New Zealand [45]. Two small contract areas for phosphorites, one offshore New Zealand $\left(4.7 \times 10^{3} \mathrm{~km}^{2}\right)$ and one offshore Namibia $\left(2.3 \times 10^{3} \mathrm{~km}^{2}\right)$, were granted mining licenses, but both were put on hold during litigation brought by environmental groups, which have lasted for many years; however, recently the Namibia operation has been given permission to proceed (Fig. 2).

Deep-sea muds enriched in REE have been recently discovered in the eastern South Pacific and the North Pacific Ocean [30]. One square patch of metal-rich mud $2.3 \mathrm{~km}$ wide might contain enough REEs to meet most of the global demand for a year [30]. Deep-sea mud containing over $5 \times 10^{3} \mathrm{mg} / \mathrm{kg}$ of total REE were reported from the western North Pacific Ocean near Minamitorishima Island, a Japanese island in the northwest Pacific Ocean, containing biogenic calcium phosphate grains (up to $22 \times 10^{3} \mathrm{mg} / \mathrm{kg}$ ) that host the high REE content [46]. The exploration for REE-rich muds was extended to the Indian Ocean with the analysis of 1338 samples from 19 Deep Sea Drilling Project/Ocean Drilling Program sites.

\subsubsection{Shallow water}

Placer deposits of heavy and weathering resistant minerals are distributed in numerous sites on continental shelves. There are three exploration targets: beach placers, which are concentrated by waves and longshore currents; drowned fluvial placers, occurring in the bottom of river channels; and eluvial or lag deposits [47]. Similar placer deposits can be expected farther offshore in relation to the location of the ancient coastline during the periods of relatively low sea level (Quaternary glaciations). Usually, the fluvial placers are the most important from a REE economic point of view. Monazite ((Ce,La) $\left.\mathrm{PO}_{4}\right)$ - and xenotime $\left(\mathrm{YPO}_{4}\right)$-bearing placer deposits, formed by erosion and weathering, are considered as a primarily geological environment for the exploration in beach and marine shallow waters $[44,48]$. Tertiary and Quaternary placers accumulate the most important REE concentrations in shallow waters, derived from granitic or high-grade metamorphic rocks. India exploits coastline minerals (i.e., ilmenite, sillimanite, garnet, zircon, monazite, and rutile); these occurrences represent around $35 \%$ of the world's total beach sand mineral deposits (Fig. 3). In India, monazite reserves are estimated to be about $5 \times 10^{6}$ tonnes, 70 to $75 \%$ of which occur in beach placers and the rest in inland and offshore areas [48]. Monazite is an important exploration target for Ce and the associated LREEs and less for HREEs such as Tb, Dy, and Gd. Concentrations of thorium and uranium make monazite a restricted 'atomic' mineral for the exploration in many beach placers. Richard's Bay in South Africa, Fort Dauphin along the southeast coast of Madagascar, and numerous placers on beaches and offshore in China (Fig. 3) are potential areas for exploitation of REE-enriched sediments [44]. Placers associated with volcanic activity occur at the Aksu Diamas placer in Turkey and in the Nea Peramos shallow-marine environment in Greece [49]. In 


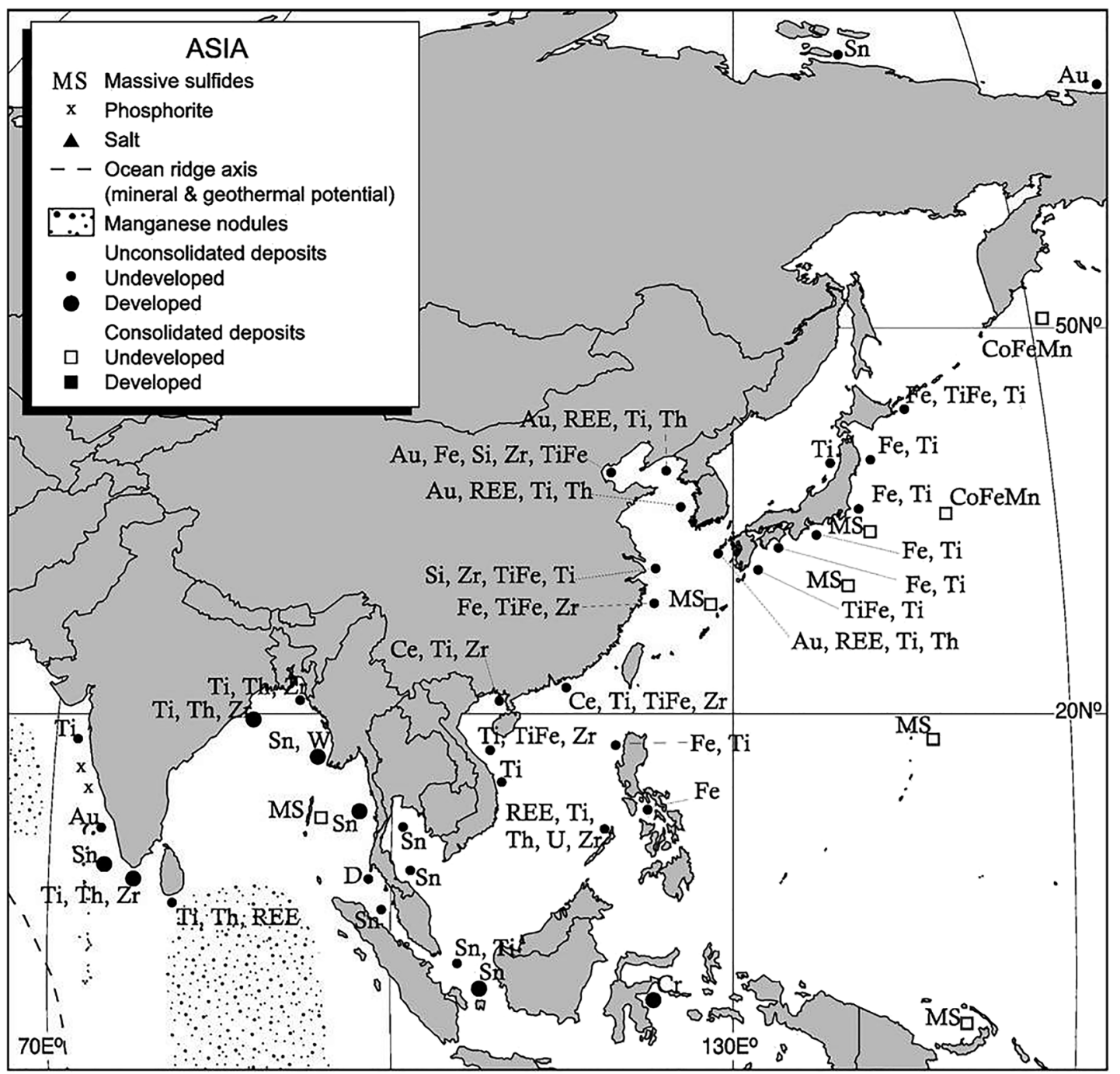

Fig. 3: Offshore minerals map of Asia showing the high concentration of REE occurrences in coastal areas from India and China [44].

southwest Turkey, the REE-rich Quaternary alkaline volcanism of Gölcük has been suggested as a possible source for heavy minerals in the Aksu Diamas placer [49, 50]. Along the northeast Aegean shelf (the coastal area of northeast Greece), the heavy mineral sands in the Nea Peramos and Strymonikos Gulf areas include REE-bearing minerals such as monazite, allanite, titanite, uraninite, zircon, and apatite [49].

\section{Ecological effects of seabed mining}

The deep sea is the prevalent ecosystem of our planet, inhabited by an estimated 10 million species. It is still recognized as the least explored area on Earth and it is rather difficult to assess the environmental impacts of ocean bed mining. The knowledge about the immense deep-sea ecosystems and species is poor. However, it is known that deep-sea ecosystems differ from those found in shallow waters, showing slow dynamics, sensitivity to anthropogenic disturbance, and high environmental stability [51]. Collecting biological baseline data of the potential mining areas is essential to evaluate properly the potential ecological impact of REE mining [22]. 


\subsection{Prospective mining areas with REE as a potential byproduct and their related ecosystems}

\subsubsection{Polymetallic nodule fields}

Most of the fauna studied from nodule fields are from the CCZ, although it is still poorly characterized [52, 53]. As expected, differences between hard-substrate (nodules) fauna and nearby sediment dwelling fauna are significant. Nodules are mainly characterized by the colonization of sessile epifauna like sponges, corals, and sea urchins (Fig. 4), while mobile deposit-feeding fauna (e.g., nematodes, copepods, polychaetes, isopods) dominate abyssal sediment. Notice that most of the sessile organisms detected are capable of colonizing these areas due to the presence of nodules that are the only hard substrate available for their larvae to settle. Ophiuroids, holothurians, and fish are also typical in these areas [53,54]. Although the areas that polymetallic nodule fields encompass are extensive, differences in the benthic communities have been appreciated. For example, faunal abundance and diversity differ between eastern and western parts of the CCZ, probably due to more surface-water productivity in the easternmost region of the $\mathrm{CCZ}$, producing more nutrients for the benthic fauna in that area [53, 54].

\subsubsection{Deep-sea hydrothermal fields}

Hydrothermal fields comprise hot springs (vents) and diffuse-flow systems on the seabed. They occur at spreading ridges and convergent plate boundaries. They form due to seawater percolation down through fissures in the ocean crust. Seawater is superheated as it approaches hot magma, becomes acidic, and dissolves minerals. As the fluid becomes hot and buoyant, it rises toward the surface of the ocean crust and mixes with cold seawater. The hot, metal-rich fluid cools rapidly, causing the precipitation of metal sulfide and sulfate minerals, which build vent structures such as chimneys and mounds (Fig. 5). Thus far, REE-rich deposits have not been found in hydrothermal systems.

Deep-sea hydrothermal vents host a unique biodiversity including exclusive native marine species. They support chemosynthetic bacteria and archaea, giant tubeworms, clams, snails, and shrimp. Bio-communities at hydrothermally active sites are of a great importance for biogeographic studies [56]. In addition, they offer valuable information for understanding the origin of life on our planet [26]. Specific vent communities along oceanic spreading centers vary on regional scales.



Fig. 4: ROV still image of a sea urchin on top of a polymetallic nodule in the CCZ [55]. 


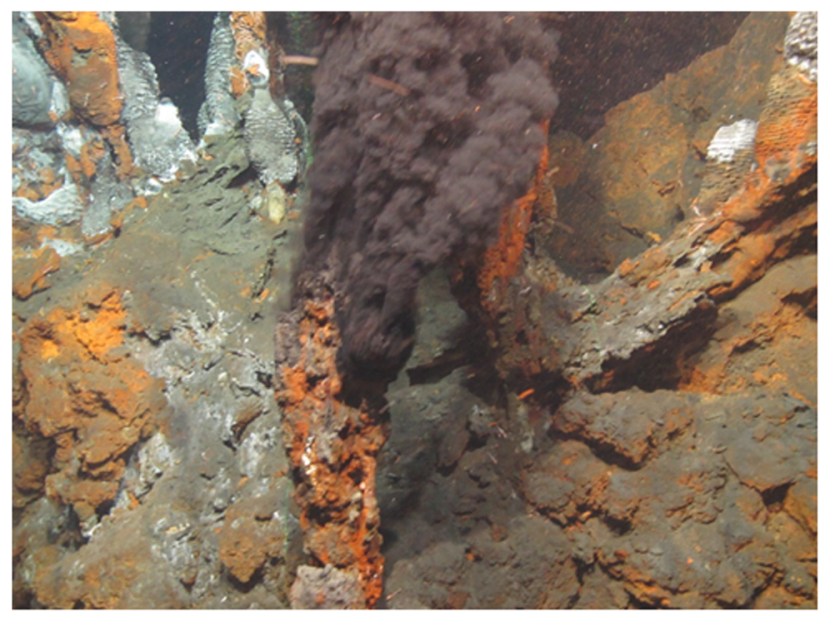

Fig. 5: ROV still image of active chimney from the Moytirra hydrothermal vent in the Middle Atlantic Ridge [57].

\subsubsection{Cobalt-rich ferro-manganese crusts on seamounts}

Seamounts are elevated structures on the seabed, originally active volcanoes that are now long extinct. Cobaltrich ferromanganese crusts appear on exposed hard rock, forming thick pavements (up to $250 \mathrm{~mm}$ thick) primarily in the western and central Pacific Ocean (PCZ) and in the south and northeast Atlantic Ocean ([58] and references therein). The steep relief of seamounts favors acceleration of water currents that can prevent sedimentation, disperse larvae and nutrients more effectively, and increase the availability of food particles for filter feeders $[54,59,60]$. The hard substratum also provides a perfect place for larvae settlement of filter feeders like sponges and corals. Stony corals, but also sponges and other sessile organisms serve other organisms (e.g., shrimp, crabs, fish) as resting, feeding, or even hiding habitats sustaining micro-ecosystems themselves. They are slow-growing fauna, needing up to thousands of years for stony corals to build complex biogenic structures [54,59]. Moreover, benthic community composition on seamounts is depth-stratified due to the variability of certain physicochemical parameters like temperature, oxygen concentration, food availability, and pressure. This implies a great enrichment in biodiversity, rendering seamounts important habitats for the global ecological enrichment of the deep-sea [59].

The grade of endemicity of the fauna on seamounts may vary depending on the distances and water currents that transport nutrients and larvae between different seamounts. Common species are reef-building scleractinian corals (e.g., Lophelia pertusa and Madrepora oculata) and the orange roughy fish ([59] and references therein). However, in open-ocean seamount settings, where crusts are likely to be mined, the generalization that seamounts are habitats with endemic fauna that form unique communities distinct in species composition from other deep-sea habitats is not supported by the weight of existing evidence [61]. Furthermore, ferromanganese crusts will likely be mined in the PCZ region at water depths of 1 to $2.5 \mathrm{~km}$, which

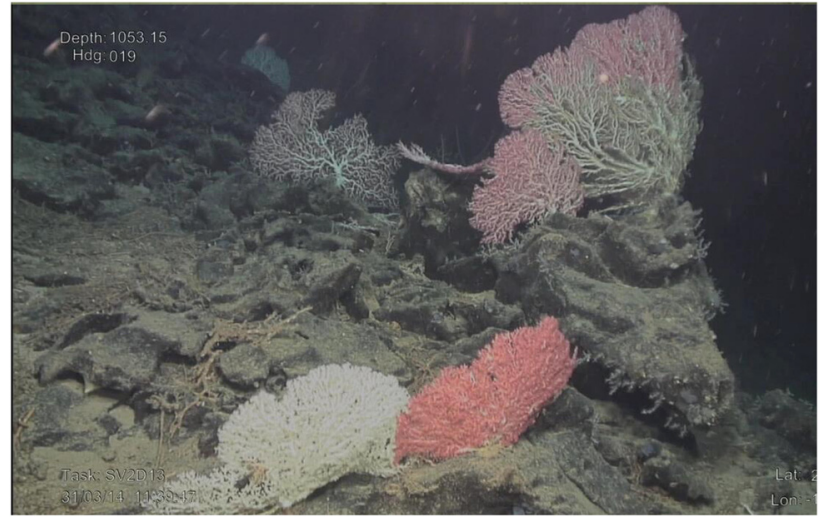

Fig. 6: ROV still image of sessile fauna (mainly corals) on top of cobalt-rich ferromanganese crusts seamount in the Necker Ridge (modified from [62]). 
is mostly within the oxygen minimum zone where biomass density is subdued [21,33]. This may not apply to continental-margin seamounts.

\subsection{Types of environmental impacts}

Seabed mining is an environmentally challenging issue. The scraping of the ocean bed by mining devices will affect deep-sea communities potentially leading to biodiversity loss and changes in the ecosystems structure. Moreover, the disturbance of these ecosystems with high numbers of endemic species could lead to the extinction of certain species, although data are not available to make this prediction confidently.

Apart from the seabed and the seawater column, potential effects might be even detected in the atmospheric (i.e., greenhouse gas emissions) and the terrestrial environment [63]. Ecological impacts comprise mainly alteration of habitat and benthic communities, sediment disturbance and plume discharges, release of toxic compounds, light and noise generation, thermal pollution, air emissions, etc. [64-67]. The classification and mitigation of impacts depends on various factors because the ecological characteristics of the marine species vary widely. Moreover, different deposits are correlated with different impacts and no comparable events are available to quantify environmental loss due to deep-sea mining activities.

\subsubsection{Habitat alteration/removal}

The most obvious impact of mining on benthic fauna is the uptake of REE deposits because it encompasses the disturbance and removal of their habitat. However, recovery of the ferromanganese crust would not remove the hard substrate needed for sessile epifauna to settle because the crusts grow on hard rock, unlike nodules. In the case of the seamounts, this would imply an impact on the microhabitats created by stony corals and sponges, which sustain many other epifauna and macrofauna (see Section 5.1.3). In the case of nodules, these sessile organisms would not be able to re-colonize the area due to the lack of a hard substrate, unless some nodules were not extracted or substitutive material was placed in the mined areas.

Physical disturbance in these habitats could cause a shift in dominant species from large sessile species to small, fast-growing, opportunistic, colonizing species, scavengers, and juveniles [68]. Many small-scale disturbance experiments have been made mostly on polymetallic nodule fields (see [69], for details). In summary, mobile and smaller organisms seem to recover easier [54, 69], while sessile megafauna, in some cases, were almost absent after 37 years [70] as expected due to the slow growth of new nodules (millions of years) [53]. Experimental simulations already address the potential impact that deep-sea mining might cause in nodule fields, although those experiments have not included placing replacement hard substrates in the mined area during long-term experiments ([53] and references therein).

The mining of hydrothermal deposits could remove chimneys leading to the flattening of the seabed, although mining active vent deposits is not being considered. Seafloor massive sulfides in active hydrothermal vents can recover relatively rapidly (from months to years) whereas those found in inactive vents would need much more time (from tens to hundreds of years) [71]. If active vent deposits were ever considered for mining and vent chimneys may reform quickly, it is still unknown whether habitats would recover or if animals would reappear [72]. According to various studies, larvae from other vent sites are transported from sites located at a distance ranging from tens or even hundreds of kilometers [71]. If hydrothermal vents responsible for the formation of polymetallic sulfides continue to be active after mining operations, the deposits could be rebuilt and colonized by fauna, mainly via the transport of larvae [73].

\subsubsection{Sediment disturbance and plume discharges}

The movement of mining devices on the seabed causes physical disturbance of the sediment that generates sediment plumes of fine material [65]. Moreover, operation phases such as mining (i.e., cutting and scraping for crusts and sulfides) and pre-processing (i.e., grinding, crushing, and washing) contribute to the generation of 
sediment or particle plumes. Plume composition is mostly inorganic particles, while a minor part of refractory organic matter may also be present. Near-bottom currents lead to turbulent mixing and dispersion of the sediment and, depending on the particle size of the suspended matter and the settling velocity, the sediment will be re-deposited either nearby or at a distance from the mining location. Thus, sediment plumes might affect the seafloor and the water column of not only the local fauna but of distal ecosystems as well, which are then indirectly impacted by mining [63]. For instance, sulfide test mining at the Solwara 1 site off Papua New Guinea indicated potentially dispersing of the plume, up to $10 \mathrm{~km}$ away [54]. The range of dispersion depends on various environmental parameters including the stratification of the water column and the depth of the surface mixed layer. In the water column, the occurrence of a sharp pycnocline blocks the vertical mixing of the suspended particulates and encourages the horizontal dispersion [66]. According to Spearman et al. [74], parameters such as flocculation, background turbidity, and internal tides cause a substantial reduction of the extent of dispersion of benthic sediment plumes. Despite the fact that various numerical models have been developed to define the transport and fate of a sediment plume and sediment particulates, there are still many uncertainties [75] about the time needed for the suspended particulates to resettle on the ocean bed and the extent of impacts on species and ecosystems.

Apart from the seabed operational plumes, discharge plumes may also be generated at the support vessel, following on-board processes [54, 71, 76-78]. They contain wastewater and fine particulates. The release of return plume into the sea will slowly settle down and suspended particulates will spread over an area of the seabed the size of which will depend on the depth at which the plume was released, the discharge volume, the prevailing ocean currents, and the vertical stratification [23, 67, 71]. Moreover, the presence of upwelling currents around seamounts could transport the plume up to the surface if released at a shallow depth [76]. However, various models suggest that if the release takes place near the seabed, most probably, it will remain at the lower level of the water column [79]. Additionally, as the propulsion system of the collector stirs up sediments, it may cause the partial or total burial of the benthic organisms [80]. The plume release in the water column may cause changes in $\mathrm{pH}$ and temperature [71, 81]. The discharge of wastewaters at the euphotic zone would impede sun light penetration and reduce photosynthesis. The reduction of plankton growth causes a domino effect on the food web. Sediment plumes may smother benthic organisms, mostly affecting filter feeders and other sessile organisms, which cannot escape from the plume deposition [54, 80].

\subsubsection{Release of toxic compounds}

The mining process and the discharge of sediment plumes may release toxic compounds such as heavy metals under suboxic or reducing conditions. Moreover, sediment disturbance may also release naturally occurring components from anoxic layers, which currently do not occur within the reach of the mining machines at any polymetallic nodule or crust contract area; this might be an issue for Peru Basin nodules, but no exploration contracts exist for that area. Metal bioavailability is unlikely because the particles expected to form the plumes are inert [76]. Otherwise, bioavailable heavy metals may cause severe health impacts on marine species, and it should be highlighted that the knowledge on the sensitivity of deep-sea fauna species to high heavy metals content is rather limited [67].

\subsubsection{Light generation}

Artificial light disturbs natural rhythms and activities of marine biota, attracting some species or discouraging others. At the sea surface, light pollution invites insects, birds, and even marine mammals [76]. Artificial light emissions will occur from seabed mineral collectors supplied with strong lights that allow for camera control of the mining operations, as well as from ROVs used for monitoring the mining process. Deep-sea organisms may have partly or totally reduced eye capacity or even fully developed eyes sensitive to bioluminescence low-light levels [67]; sunlight penetrates into the water column to a maximum depth of $1 \mathrm{~km}$, although only $1 \%$ of the sunlight is left at $100 \mathrm{~m}$. 


\subsubsection{Noise generation}

Underwater ambient noise is generated at the seabed by both the collector machinery and the riser system plus within the water column by lift and release pipes [67]. Noise can travel over large distances. Moreover, support vessels generate noise on the sea surface. This anthropogenic non-stop noise will likely influence deep-sea species like fish and marine mammals. Marine mammals and deep-sea fish use sensitive acoustic changes for communication and navigation and this kind of disturbance may cause significant impacts [72, 76]. Potential impacts include behavior change, hearing damage, and masking acoustic communication [23].

\subsubsection{Thermal pollution}

Dewatering discharges at depth may cause local heating of the seawater. When the seawater temperature rises, the content of dissolved oxygen may decrease locally. Discharges in surface waters are not anticipated [76].

\subsubsection{Air emissions}

Major sources of air emissions include waste incineration, combustion engines, and turbines [76]. Air pollutants derive from maritime fuels. To mitigate these impacts, various technological innovations for fuel saving, along with the use of renewable energy sources and the adoption of measures for power-generation optimization should be considered [82].

\subsubsection{Discharges to water}

Cooling waters are discharged to the ocean from ships. They may contain various chemicals, such as biocide antifouling agents, corrosion inhibitors, etc. [76].

\subsubsection{Removal of ambient water}

Large volumes of ambient water are usually used during the excavation and pre-processing operations as well as for the dilution of the ore and the successive pumping of the slurry to the surface; potential effects include fish disturbances while various zooplanktonic species might be sucked up with the water mass and killed [67].

\subsubsection{Destruction of marine genetic resources}

There are concerns that mining activities may destroy marine genetic resources that could contain products with a high pharmaceutical potential for new treatments and therapies [72]. It is essential that pre-mining baseline studies limit this possibility.

\subsection{Ecological restoration}

Anthropogenic disturbances at deep-sea should include activities for restoration of the disturbed ecosystems. Deep-sea restoration is a lasting investment that includes many stakeholders and investors. It is about two to three times more expensive than in swallow waters. The cost of deep-sea restoration can be reduced through economies of scale, development of specific underwater devices, and when restoration activities occur concurrent with deep-sea mining [83].

In order to enable the rehabilitation of the mining area and the recovery of the local biota, specific approaches are applied. The setting of un-mined biological corridors (temporary refuges) within a mining area serves as a reference site and a source of colonists [84]. Networks of permanent and temporary set-aside areas turn to be also sources of colonists [85].The positioning of artificial substrates offers topographic relief and 
structural stability for the relocation of animals. The effectiveness of anthropogenic restoration measures is higher in ecosystems with natural resistance like in hydrothermal vent ecosystems. In vents, natural recovery leads to a passive (unassisted) restoration.

Further progress in restoration science, technology, and training will improve the protection of deep-sea ecosystems.

\section{In search of sustainable exploitation of seabed mineral deposits containing REEs}

The possibility of no net biodiversity loss by mining is unconceivable. The removal of REE-containing polymetallic nodules implies the disappearance of the substrate that sustains the local ecosystems (see Section 5.2.1). Moreover, most mining-induced loss may last forever on a human timescale, given the very slow natural rates of recovery in affected ecosystems determined from small-scale disturbance experiments [86], although this is poorly studied. Given this difficult scenario, different studies are addressing possible strategies to mitigate and reduce the ecological impact of deep-sea mining [87]. In 2017, C. L. Van Dover addressed the common requirement of a four-tier mitigation hierarchy strategy for extractive industries to prevent biodiversity loss. In order of priority, industries should avoid, minimize, remediate, or ultimately offset the ecosystem ([86] and references therein). Among the various practical ways proposed for polymetallic nodules, we refer to the following:

i) Using fitting shrouds to cutting equipment to avoid dispersion of sediment plumes and burial of organisms [86].

ii) Leaving a proportion of nodules on the seabed that facilitates re-colonization [23].

iii) Replacing REE-containing nodules with other materials that mimic the hard substrata needed by most microhabitat-forming organisms (i.e., corals).

The maintenance of a Preservation Reference Zone in the proximity of the exploited area could also favor easier recolonization, noticing that the new community would be similar to the pre-mining one [88].

Because deep-sea mining lacks reference events, predicting ecological damage is difficult based on models, but the real magnitude can be quantified once exploitation activities start. It is therefore important to perform exhaustive preliminary exploration cruises to investigate the area and its ecosystems and implement policies that restrict mining and protect certain areas, e.g., creating a catalog in which ecosystems are classified according to their mining and ecological interests [88]. Moreover, research studies are proposing different approaches and analyses to achieve ultimately sustainable deep-sea mining activities, e.g. a three-step adaptive approach and a life-cycle analysis (see $[63,89]$ for details).

Although significant progress has been made towards the acquisition of knowledge regarding deep-sea ecology and the potential impact of deep-sea mining, it is broadly accepted that it is still not possible to issue a conclusive risk assessment of the effects of large-scale commercial seabed mining [87].

\section{Socio-economic impacts of deep-sea mining}

The socio-economic impacts of deep-sea mining will mainly occur at the end of the value chain where mineral resources will be processed on land and where they may have an influence on the price development of the global metal market. On the other hand, there will be new opportunities for labor in areas where the processing of deep-sea resources will take place, potentially promoting the increase in wealth and well-being. Additionally, processing of resources will lead to new competition of land use, forest destruction, and water pollution. However, this is a development, which is not restricted to deep-sea mining and may be a negative side effect of any mining activity. 
More specific to deep-sea mining, mining of metals such as manganese, cobalt, and REEs may have a significant effect on the global metal market. Although there will be no significant impact on the global supply and prices of metals recovered by one or two companies mining at once for manganese nodules with about 2 to 3 million dry tonnes of nodules per year for each, five companies mining in parallel for nodules may have a tremendous effect on manganese but also on cobalt and some of the REEs [90]. The oversupply of these metals to the global market may lead to decreasing prices and this will have a negative effect on the economies of developing or emerging countries such as South Africa, Ghana, Gabon, or DR Congo, which largely depend on the export of those metals. To prevent such negative effects of deep-sea mining, the ISA is tasked according to the UNCLOS, article 151, to initiate mitigation measures to assist the adaption of national economies to such adverse developments should they occur.

Apart from these two aspects, another social impact of deep-sea mining could be the large-scale drift of sediment plumes, which might influence fishing grounds within the EEZ of countries but also in international waters. For nodule deposits within the CCZ of the northeast Pacific, this impact is very unlikely, but it may apply for mining ferromanganese crusts on seamounts or massive sulfides in back-arc basins because those deposits often occur within the EEZ of countries and they are located in shallower waters.

Social impacts are supposed to play a role if it comes to marine mining within the EEZ of countries rather than in international waters. For instance, the company "Nautilus Minerals" faced strong opposition to their plans to mine the Solwara 1 massive sulfide deposit in the national waters of Papua New Guinea. Fishermen living in the area, where marine mining would occur, were skeptical towards the environmental impacts of such undertakings, because of negative experience with terrestrial mining and its environmental consequences. Such concerns could cause conflicts between those local communities, which are in favor of mining because it offers possibilities to make a living, and those that oppose these projects because they fear environmental consequences. Often, these fears arise because marine mining may directly interfere with their business such as fishing or tourism. Nevertheless, the traditional relation between the local people and the ocean that may be the place of their ancestors and/or the site of religious traditions must also be taken into account.

The Cook Islands, however, are a positive example how to make marine mining work for the local people. The main prerequisites, for a positive perception of marine mining in the local community, are transparency and contribution. The Cook Islands is a developing state consisting of many islands with a large EEZ hosting a tremendous resource potential for such important metals like cobalt and the REE-as mentioned, the Cook Islands nodules have the highest contents of cobalt and REE among the main nodule fields [36]. In order to diversify the national income, which currently mainly consists of fishery and tourism, as well as to decrease its dependency on New Zealand, the government of the Cook Islands has developed management of their marine mineral resources to the stage of exploration leasing. All relevant stakeholders including the religious and traditional leaders participated in a long-term information process, which led to the development of a national Marine Mining Act that involves both environmental aspects and local sharing of future profits. Based on this Act, the first exploration licenses have been granted and according to current knowledge, the prospective areas within the Cook Islands EEZ have a potential of about $12.1 \times 10^{9}$ wet tonnes of Mn nodules [36, 91]. Thus, marine mining of manganese nodules could lead to a long-term prosperity of the local community. Therefore, and because of the open and transparent process, the majority of the local communities support a possible marine mining in the Cook Islands EEZ. Opposition towards marine mining, however, is caused mainly by globally operating environmental organizations [91].

\section{Marine resource mining versus land-based mining for REEs}

The economic feasibility of REE deposits can be assessed based on the ore and TREO tonnage, the ore grade, the relative REO distribution, and the basket price. The relative REO distribution is given as the REO/TREO percentage. The term basket price means the potential price without considering the ore grade or total recovery rate [92]. 
Seabed mineral resources have relatively low TREO contents, low TREO grades, and significant TREO yields compared to the large terrestrial LREE-rich carbonatite-hosted deposits but are comparable to the terrestrial HREE-rich ion-adsorption clay deposits [92]. The Clarion-Clipperton Fe-Mn nodule Zone in the northeast Pacific and the Prime Fe-Mn Crust Zone in the central Pacific are areas of greatest economic interest for nodules and crusts respectively [21]. Polymetallic nodules from the Korean tenement at the CCZ have an average TREO content of $0.13 \%$ (ranging from 0.037 to $0.302 \%$ ) and a TREO grade of $0.12 \%$. It was estimated that the ore tonnage is $188 \times 10^{6}$ tonnes and the TREO yield is $230 \times 10^{3}$ tonnes. Their total basket price is $17.93 \mathrm{USD} / \mathrm{kg}$. The TREO tonnage of polymetallic nodules within the total Korean tenements is approximately $1 \times 10^{6}$ tonnes [92]. REE-bearing deep-sea sediments from the CCZ have a mean TREO content of $0.049 \%$ (varying from 0.015 to $0.115 \%$ ) and a TREO grade of $0.13 \%$. It was assessed that the ore tonnage is $16.5 \times 10^{9}$ tonnes and the total basket price is $26.05 \mathrm{USD} / \mathrm{kg}$. The TREO yield from REE-bearing deep-sea sediments from the Korean tenements was estimated to be approximately $8 \times 10^{6}$ tonnes [92]. Ferromanganese crusts from seamounts near the Marshall Islands, in the northwest Pacific Ocean, have a mean TREO content of $0.185 \%$ (varying between 0.086 and $0.387 \%$ ). Ferromanganese crusts are also characterized by a large TREO tonnage. Their total basket price is $15.14 \mathrm{USD} / \mathrm{kg}$ [92]. Polymetallic nodules have a slightly higher total basket price than ferromanganese crusts because they have higher REE elements Nd, Pr, and Dy and lower La and Ce contents. The average TREO content of the deep-sea sediments is approximately $1 / 3$ that of the nodules and crusts. Deep-sea sediments have approximately double the total basket price of nodules and crusts as they have nearly double the REE elements Nd, Pr, Dy, Sm, Eu, Gd, Y, and Tb and half the La and Ce contents [92].

Manganese nodules from the Cook Islands EEZ, in the central South Pacific, contain high TREE content $(0.167 \%)$, corresponding to almost 15 to $21 \%$ of the terrestrial reserves of REY [37]. The Cook Islands EEZ covers $1977 \times 10^{3} \mathrm{~km}^{2}$ and it has a high nodule abundance, up to $58 \mathrm{~kg} / \mathrm{m}^{2}$ in a few isolated areas. The CIs nodules show higher nodule abundance and are more enriched in REE in comparison with the CCZ [37].

Deep-sea sediments from the Japanese EEZ around Minamitorishima Island (also called Marcus Island), in the western North Pacific Ocean, consist of highly to extremely REE-rich mud, containing $2 \times 10^{3}$ to more than $5 \times 10^{3} \mathrm{mg} / \mathrm{kg} \mathrm{REE}$, with a high enrichment in Y and the HREE (accounting for $44 \%$ of the total amount of REE in the Japanese Minamitorishima EEZ). It was estimated that TREE exceeds $16 \times 10^{6}$ tonnes TREO, with an average TREE content of $964 \mathrm{mg} / \mathrm{kg}$. The most promising area, with the highest REY resource potential, covers $105 \mathrm{~km}^{2}$. It has an average TREY content of more than $1.7 \times 10^{3} \mathrm{mg} / \mathrm{kg}$ and the resource estimated to be $1.2 \times 10^{6}$ tonnes [46].

Land-based REE deposits have variable TREO grades, ranging from 0.01 to $12 \%$, however $60 \%$ of these deposits have a TREO grade lower than $2 \%$. In comparison with deep-sea mineral deposits, the land-based REE deposits have higher TREO contents. The land-based REE deposit at Mountain Pass (in USA) has a TREO content of 8.0 to $8.9 \%$, a TREO grade of $8.0 \%$, and an ore tonnage of $17 \times 10^{6}$ tonnes; the contained TREO is 1333 kilotonnes and the total basket price is $9.06 \mathrm{USD} / \mathrm{kg}$. At Mount Weld Central Lanthanide Deposit (in Australia), the TREO content was estimated to be 7.9 to $15.5 \%$, the TREO grade was 8.8 to $10.8 \%$, and the ore tonnage was $9.9 \times 10^{6}$ to $15 \times 10^{6}$ tonnes; the contained TREO is 1069 to 1320 kilotonnes and the total basket price is $12.22 \mathrm{USD} / \mathrm{kg}$. At Bayan Obo deposit (in China), the TREO content and grade are $6 \%$, the ore tonnage is 800 million tonnes, the contained TREO is $48 \times 10^{3}$ kilotonnes, and the total basket price is $11.99 \mathrm{USD} / \mathrm{kg}$. At Nolans Bore deposit (in Australia), the TREO content is $2.8 \%$, the TREO grade is $2.6 \%$, the ore tonnage is $56 \mathrm{Mt}$, the contained TREO is 1456 kilotonnes, and the total basket price is $14.87 \mathrm{USD} / \mathrm{kg}$. At Strange Lake deposit (in Canada), the TREO content was estimated to be 0.97 to $1.16 \%$, the TREO grade was $0.09 \%$, the ore tonnage was 492 million tonnes, the contained TREO was 443 kilotonnes, and the total basket price was $25.75 \mathrm{USD} / \mathrm{kg}$. At Bear Lodge deposit (in USA), the TREO content is 2.6 to $3.2 \%$, the TREO grade is 2.6 to $2.8 \%$, the ore tonnage is $14 \times 10^{6}$ to $27 \times 10^{6}$ tonnes, the TREO content is 395 to 686 kilotonnes, and the total basket price is $11.56 \mathrm{USD} / \mathrm{kg}$ [92].

Compared with terrestrial reserves, nodules in the CCZ have more $\mathrm{Tl}, \mathrm{Mn}, \mathrm{Te}, \mathrm{Ni}, \mathrm{Co}$, and $\mathrm{Y}$, containing also significant amounts of $\mathrm{Cu}, \mathrm{Mo}, \mathrm{W}, \mathrm{Li}, \mathrm{Nb}$, and REEs, while Fe-Mn crusts in the PCZ have significantly more Mn, $\mathrm{Tl}$, Te, Co, and Y, being also enriched in Bi, REE, Nb, and W [21]. Large terrestrial REE deposits have below $1 \%$ HREEs; nevertheless, the PCZ crusts, CCZ nodules, Cook Islands nodules, and the seamount phosphorites have 
respectively 18, 26, 17, and $60 \%$ HREEs complement of the total REEs [32, 93]. This is crucial because the HREEs have the greatest economic value. It is evident that marine deposits (sediments, $\mathrm{Fe}-\mathrm{Mn}$ crusts and polymetallic nodules) offer a promising alternative supply of REE. The great current challenge is to develop cost-effective, low-carbon, and separation methods for the REE exploration [94].

\section{European projects for marine minerals}

The European, National, and International programs related to the research, exploration, and exploitation of marine minerals, and environmental impact studies of marine mining activities, will play pivotal roles in the emerging "Blue Economy" and sustainable industrial growth. The EC's Blue Growth strategy estimated that "By 2030, $10 \%$ of the world's minerals, including cobalt, copper, and zinc could come from the ocean floors. Global annual turnover of marine mineral mining can be expected to grow from virtually nothing to $€ 10$ billion by 2030" [95]. The EU research programs are funding projects to increase knowledge about seabed minerals, marine minerals exploration, extraction technologies, and environmental issues by research organizations and industry. A literature review has concluded that these studies employ differing objectives and scientifictechnical criteria. Born to satisfy proactive European strategies such Marine Knowledge 2020 and the Blue Growth strategy, the data collation project EMODnet-Geology provides a basic catalogue of nine different types of submarine mineral deposits in all European seas with associated metadata and attributes where available [96]. Initiatives like the Atlantic Action Plan, the Atlantic Ocean Research Alliance, and the Atlantic Seabed Mapping International Working Group concentrate on the need to complete Atlantic seabed mapping and progress open-source data availability [97]. Projects such as Blue Mining, Blue Nodules, Marine E-Tech, and MIDAS are collaboratively working on marine resource discovery, resource assessment, and exploitation technologies [77, 98-100].

In 2018, the EC funded the project GeoERA-MINDeSEA to map and to establish the metallogenic context for different seabed mineral deposits with economic potential in the pan-European setting. It is a joint contribution of 12 national Geological Survey Organizations and Marine Institutes from 8 European countries, the USA, and Russia. The project is part of GeoERA, an ERA-NET action under Horizon 2020 "Establishing the European Geological Surveys Research Area to deliver a Geological Service for Europe" [101]. This project addresses an integrative metallogenetic study of principal types of seabed mineral resources (hydrothermal sulfides, ferromanganese crusts, phosphorites, marine placers, and polymetallic nodules) in the European Seas, and their associated critical raw materials including REE. This study will publish marine resource information, case studies, and maps; identify areas for responsible resource exploration and extraction; and inform management and Marine Spatial Planning [102]. More than 600 mineral occurrences and 1045 individual analyzed samples are reported in the MINDeSEA database and maps (Fig. 7). The dataset contains five principal levels of information with multiple attributes for each occurrence: geographical, metallogenic, economic, geochemical, and environmental data. The map shows resources of about 15 million $\mathrm{km}^{2}$ in the Arctic and Atlantic oceans and the Mediterranean, Baltic, and Black Seas, from shallow waters up to $6000 \mathrm{~m}$ water depth. Co-rich ferromanganese crusts and phosphorites from the Macaronesia (Portugal and Spain) and ferromanganese deposits from the Arctic (Norway and Russia) represent potential areas for mining exploration. In addition, there is a promising prospective in placer deposits from the east Mediterranean coasts (Greece and Cyprus), the Variscan Belt (UK, France and Spain), the Arctic Ocean (Russia, Norway and Denmark) and the Baltic Sea (Poland and Latvia). Accumulations of heavy minerals include monazite, ilmenite, rutile, zircon, garnet, gold, diamonds, cassiterite, and magnetite.

\section{Exploration-exploitation versus preservation of the global ocean}

The mineral resource potential of ferromanganese crusts, nodules, and phosphorites in the global ocean is not well known. It is essential that marine mineral deposits be evaluated using methods applied to land-based 


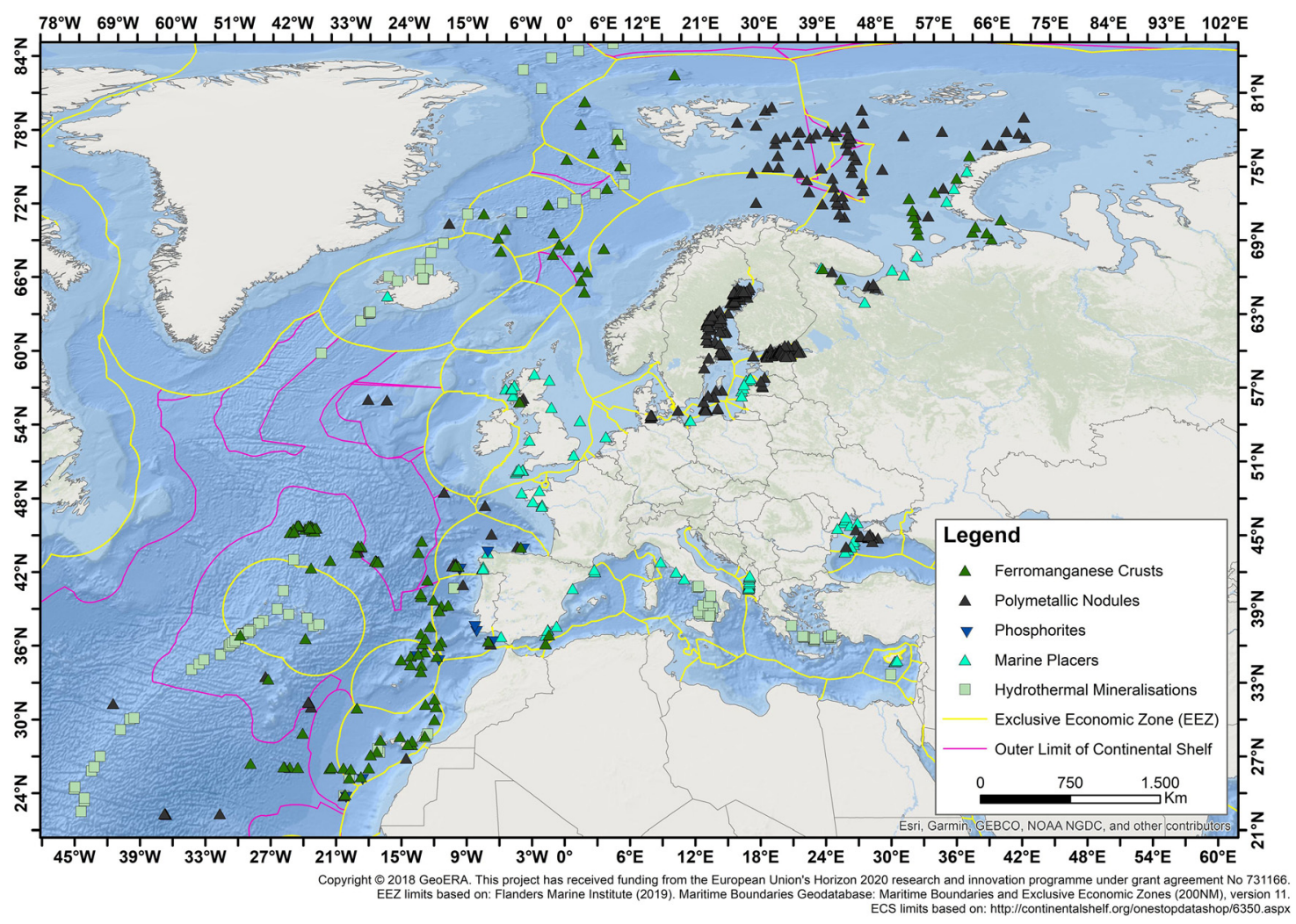

Fig. 7: MINDeSEA compilation map by May 2020 of seabed mineral occurrences in the pan-European seas.

mineral deposits so that their relative importance can be understood as potential sources of many strategic and critical minerals and metals including REE. Extracting minerals from the deep sea represents an enormous scientific and technological challenge for humankind. Precise evaluations of nodules seafloor coverages and thickness measurements in crusts and phosphorites in addition to clean methods of separation of minerals from substrates will be engineering challenges in the next years. High nodule abundance and the thickest crust and phosphorite deposits and their occurrence associated in the same site are a great environmental advantage because smaller areas would be required to supply a potential 20 year mine site, resulting in lower environmental impact. The global ocean can play a key role in the mitigation of climate change and also in improving the sustainable use of mineral resources. These issues include judicious consideration among the fisheries and minerals industries, offshore wind production, and the preservation of aquatic environments and ecosystems. Considerable improvement in our knowledge of the oceans and seas is necessary to develop a sustainable "Blue Economy" and in obtaining social license. However, seabed geology and ecosystems are widely unexplored, and new geological and environmental studies are required to address the impacts of potential mining activities. New developments focusing on applying new technologies for deep-sea exploration, mining, and mineral processing will be required to minimize global ecological damage. In addition, a regulatory framework for minerals extraction and marine spatial planning are necessary for seabed mining sector development.

\section{Conclusions}

Seabed mineral deposits are the larger but least explored resource of critical elements and base metals on Earth. They usually have lower REE grades than the large land-based carbonatite-hosted deposits but form greater potential volumes. At present, deep seafloor mining has not started in any part of the world, but various 
international mining companies have signed contracts to explore the seabed. Deep-sea minerals that are likely to be mined in the near future include polymetallic nodules, cobalt-rich ferromanganese crusts, massive sulfides, metal-rich muds, and phosphorites. Major obstacles of concern in deep-sea mining relate to the potential environmental impacts. The deep-sea hosts many of the most pristine and poorly studied ecosystems on Earth and mining may become an important and challenging stressor on the marine environment. Therefore, it is important that regulations and practices for ocean mining are formally established and deepsea mineral resources are effectively managed and exploited. Additionally, as the growing need for resources is an indicator of a society geared to throw-away consumption, the adoption of circular, resource efficient, and responsible mineral value chains will contribute crucially to our efforts to achieve a sustainable development.

\section{Membership of sponsoring body}

Membership of the IUPAC Chemistry and the Environment Division Committee for the 2018-2019 was as follows:

President: Prof. Rai Kookana (Australia); Past President: Prof. Petr S. Fedotov (Russia); Vice President: Prof. Hemda Garelick (UK); Secretary: Prof. Roberto Terzano (Italy); Titular Members: Prof. Doo Soo Chung (South Korea), Prof. Annemieke Farenhorst (Canada), Prof. Nadia G. Kandile (Egypt), Dr. Laura L. McConnell (USA), Prof. Irina Perminova (Russia), Prof. Fani L. Sakellariadou (Greece); Associate Members: Dr. Wenlin Chen (USA), Dr. Bradley Miller (USA), Prof. Diane Purchase (UK), Prof. Edgard Resto (Puesto Rico), Dr. John B. Unsworth (UK), Prof. Baoshan Xing (USA); National Representatives: Prof. Cristina Delerue Alvim de Matos (Portugal), Prof. Michal Galamboš (Slovakia), Prof. Ester Heath (Slovenia), Prof. Yong-Chien Ling (China/ Tapei), Prof. Bulent Mertoglu (Turkey), Prof. Gloria Obuzor (Nigeria), Dr. Bipulbehari Saha (India), Dr. Tiina Sikanen (Finland), Prof. Weiguo Song (China), Prof. Stefka Tepavitcharova (Bulgaria).

Membership of the IUPAC Chemistry and the Environment Division Committee for the 2020-2021 was as follows:

President: Hemda Garelick (UK); Past President: Rai Kookana (Australia); Vice President: Roberto Terzano (Italy); Secretary: Annemieke Farenhorst (Canada); Titular Members: Doo Soo Chung (South Korea), Petr S. Fedotov (Russia), Bradley Miller (USA), Diane Purchase (UK), Fani L. Sakellariadou (Greece), Weiguo Song (China); Associate Members: Nadia Kandile (Egypt), Yong-Chien Ling (Taiwan), Irina Perminova (Russia), Bipul Behari Saha (India), John B. Unsworth (UK), Baoshan Xing (USA); National Representatives: Vladimir Beškoski (Serbia); Cristina Delerue-Matos (Portugal); Michal Galamboš (Slovakia), Joon Ching Juan (Malaysia), Bulent Mertoglu (Turkey), Oluseun Elizabeth Popoola (Nigeria), Yehuda Shevah (Israel), Tiina Sikanen (Findland), Monthip Sriratana (Thailand); Emeritus member: Laura L. McConnell (USA).

Research funding: This document was developed as a part of IUPAC, Funder Id: https://doi.org/10.13039/ 100006987 Project No. 2018-039-3-600 (https://iupac.org/project/2018-039-3-600), led by Fani Sakellariadou (Task Group Chair). Task Group Members for this project were: Francisco J. Gonzalez, James R. Hein, Blanca Rincón-Tomás, Nikolaos Arvanitidis, and Thomas Kuhn.

\section{List of acronyms}

$\begin{array}{ll}\text { AORA } & \text { Atlantic Ocean research alliance } \\ \text { CCZ } & \text { Clarion-Clipperton zone } \\ \text { Cls } & \text { Cook Islands } \\ \text { EEZ } & \text { exclusive economic zone } \\ \text { GeoERA } & \text { geological service for Europe } \\ \text { HREE } & \text { heavy rare earth element } \\ \text { ISA } & \text { International Seabed Authority }\end{array}$




$\begin{array}{ll}\text { LREE } & \text { light rare earth element } \\ \text { NERC } & \text { Natural Environment Research Council } \\ \text { PCZ } & \text { prime Fe-Mn crust zone } \\ \text { REE } & \text { rare earth element } \\ \text { REO } & \text { rare earth element oxides } \\ \text { ROV } & \text { remotely operated vehicle } \\ \text { SMS } & \text { seafloor massive sulfides } \\ \text { TREO } & \text { total rare earth element oxides } \\ \text { TREE } & \text { total rare earth elements } \\ \text { UNCLOS } & \text { United Nations Convention on the Law of the sea }\end{array}$

\section{References}

[1] United Nations Department of Economic and Social Affairs. Population, Dynamics, World Population Prospects, United Nations, New York (2019).

[2] USGS. Mineral Commodity Summaries 2020. US Geological Survey (2020), https://doi.org/10.3133/mcs2020.

[3] G. P. Hatch. Elements 8, 341 (2012).

[4] S. Massari, M. Ruberti. Resour. Pol. 38, 36 (2013).

[5] K. Binnemans, P. T. Jones. J. Sustain. Met. 1, 29 (2015).

[6] X. Du, T. E. Graedel. Sci. Rep. 1, 145 (2011).

[7] European Parliament, the Council, the European Economic and Social Committee and the Committee of the Regions on the 2017 List of Critical Raw Materials for the EU, Brussels (2017).

[8] H. A. L. Elliott, F. Wall, A. R. Chakhmouradian, P. R. Siegfried, S. Dahlgren, S. Weatherley, A. A. Finch, M. A. W. Marks, E. Dowman, E. Deady. Ore Geol. Rev. 93, 38 (2018).

[9] P. L. Verplanck, A. N. Mariano, A. Mariano. In Rare Earth and Critical Elements in Ore Deposits, P. Verplanck, M. Hitzman (Eds.), pp. 5-32, Society of Economic Geologists, Littleton, Colorado (2016).

[10] J. Dostal. In Rare Earth and Critical Elements in Ore Deposits, P. Verplanck, M. Hitzman (Eds.), pp. 33-54, Society of Economic Geologists, Littleton Colorado (2016).

[11] J. B. Hedrick, S. P. Sinha, V. D. Kosynkin. J. Alloys Compd. 250, 467 (1997).

[12] L. N. Kogarko, C. T. Williams, A. R. Woolley. Mineral. Petrol. 74, 1 (2002).

[13] D. Holtstam, U. B. Andersson, C. Broman. J. Mansfeld. Miner. Depos. 49, 933 (2014).

[14] E. A. Deady, E. Mouchos, K. Goodenough, B. J. Williamson, F. Wall. Mineral. Mag. 80, 43 (2016).

[15] A. Berger, E. Janots, E. Gnos, R. Frei, F. Bernier. Appl. Geochem. 41, 218 (2014).

[16] S. Jaireth, D. M. Hoatson, Y. Miezitis. Ore Geol. Rev. 62, 72 (2014).

[17] B. G. Lottermoser. Lithos 24, 151 (1990).

[18] G. Estrade, E. Marquis, M. Smith, K. Goodenough, P. Nason. Ore Geol. Rev. 112 (2019), https://doi.org/10.1016/j.oregeorev. 2019.103027.

[19] RMSG Raw Materials Supply Group. Background Information for the Joint Meeting of the EIP Raw Materials Sherpa Group and the Raw Materials Supply Group, DG Growth, European Commission (2019).

[20] E. Balomenos, P. Davris, E. Deady, J. Yang, D. Panias, B. Friedrich, K. Binnemans, G. Seisenbaeva, Ca. Dittrich, P. Kalvig. Johns. Matthey Technol. Rev. 61, 142 (2017).

[21] J. R. Hein, K. Mizell, A. Koschinsky, T. A. Conrad. Ore Geol. Rev. 51, 1 (2013).

[22] ISA. International Seabed Authority, Kingston, Jamaica (2020).

[23] K. A. Miller, K. F. Thompson, P. Johnston, D. Santillo. Front. Mar. Sci. 4, 418 (2018).

[24] J. L. Mero. Econ. Geol. 57, 747 (1962).

[25] H. Bäcker, M. Schoell. Nat. Phys. Sci. 240, 153 (1972).

[26] J. B. Corliss, J. Dymond, L. I. Gordon, J. M. Edmond, R. P. von Herzen, R. D. Ballard, K. Green, D. Williams, A. Bainbridge, K. Crane, T. H. van Andel. Science 203, 1073 (1979).

[27] K. C. MacDonald, K. Becker, F. N. Spiess, R. D. Ballard. Earth Planet. Sci. Lett. 48, 1 (1980).

[28] P. Halbach, F. T. Manheim, P. Otten. Erzmetall 35, 447 (1982).

[29] D. S. Kelley, J. A. Karson, D. K. Blackman, G. L. Früh-Green, D. A. Butterfield, M. D. Lilley, E. J. Olson, M. O. Schrenk, K. K. Roe, G. T. Lebon, P. Rivizzigno. Nature 412, 145 (2001).

[30] Y. Kato, K. Fujinaga, K. Nakamura, Y. Takaya, K. Kitamura, J. Ohta, R. Toda, T. Nakashima, H. Iwamori. Nat. Geosci. 4, 535 (2011).

[31] J. R. Hein, A. Koschinsky, P. Halbach, F. T. Manheim, M. Bau, J. K. Kang, N. Lubick. In Manganese Mineralization: Geochemistry and Mineralogy of Terrestrial and Marine Deposits, K. Nicholson, J. R. Hein, B. Buhn, S. Dasgupta (Eds.), pp. 123-138, Special Publication Geological Society of London, London (1997). 
[32] J. R. Hein, A. Koschinsky, M. Mikesell, K. Mizell, C. R. Glenn, R. Wood. Minerals 6, 88 (2016).

[33] M. Benites, C. Millo, J. Hein, B. N. Nath, B. Murton, D. Galante, L. Jovane. Minerals 8, 488 (2018).

[34] J. R. Hein, A. Koschinsky, M. Bau, F. T. Manheim, J. K. Kang, L. Roberts. In Handbook of Marine Mineral Deposits, D. S. Cronan (Ed.), pp. 239-279, CRC Press, Boca Raton, Florida (2000).

[35] F. J. González, L. Somoza, J. R. Hein, T. Medialdea, R. León, V. Urgorri, J. Reyes, J. A. Martín-Rubí. Geochem. Geophys. Geosyst. 17 (2016).

[36] J. R. Hein, F. Spinardi, N. Okamoto, K. Mizell, D. Thorburn, A. Tawake. Ore Geol. Rev. 68, 97 (2015).

[37] J. R. Hein, T. A. Conrad, R. E. Dunham. Mar. Georesour. Geotechnol. 27, 160 (2009).

[38] A. Usui, M. Someya. In Manganese Mineralization: Geochemistry and Mineralogy of Terrestrial and Marine Deposits, K. Nicholson, J. R. Hein, B. Bühn, S. Dasgupta (Eds.), pp. 177-198, Geological Society of London Special Publication No. 119, London (1997).

[39] E. Marino, F. J. González, L. Somoza, R. Lunar, L. Ortega, J. T. Vázquez, J. Reyes, E. Bellido. Ore Geol. Rev. (2017), https://doi. org/10.1016/j.oregeorev.2016.10.00.

[40] A. Usui, K. Nishi, H. Sato, Y. Nakasato, B. Thornton, T. Kashiwabara, A. Tokumaru, A. Sakaguchi, K. Yamoaka, S. Kato, S. Nitahara, K. Suzuki, K. Ijima, T. Urabe. Ore Geol. Rev. (2016), https://doi.org/10.1016/j.oregeorev.2016.09.03.

[41] E. Marino, F. J. González, R. Lunar, J. Reyes, T. Medialdea, M. Castillo-Carrión, E. Bellido, L. Somoza. Minerals 8, 285 (2018).

[42] J. M. McArthur, J. N. Walsh. Chem. Geol. 47, 191 (1984).

[43] M. Benites, J. R. Hein, K. Mizell, T. Blackburn, L. Jovane. Minerals 10, 349 (2020).

[44] P. A. Rona. Ore Geol. Rev. 33, 618 (2008).

[45] H. R. Kudrass. In Phosphorite Deposits on the Chatham Rise of New Zealand; Results of a Prospection Cruise with R/V Sonne, U. von Rad, H. R. Kudrass (Eds.), Vol. D65, pp. 179-194, BGR, Hannover (1984).

[46] Y. Takaya, K. Yasukawa, T. Kawasaki, K. Fujinaga, J. Ohta, Y. Usui, K. Nakamura, J. Kimura, Q. Chang, M. Hamada, G. Dodbiba, T. Nozaki, K. Iijima, T. Morisawa, T. Kuwahara, Y. Ishida, T. Ichimura, M. Kitazume, T. Fujita, Y. Kato. Sci. Rep. 8, 8 (2018).

[47] H. R. Kudrass. In Handbook of Marine Mineral Deposits, D. S. Cronan (Ed.), pp. 3-26, CRC Press, Boca Raton, FL (2000).

[48] V. Balaram, Geosci. Front. 10, 1285 (2019).

[49] K. M. Goodenough, J. Schilling, E. Jonsson, P. Kalvig, N. Charles, J. Tuduri, E. A. Deady, M. Sadeghi, H. Schiellerup, A. Mü“ller, G. Bertrand, N. Arvanitidis, D. G. Eliopoulos, R. A. Shaw, K. Thrane, N. Keulen. Ore Geol. Rev. 72, 838 (2016).

[50] A. Papadopoulos, I. T. Tzifas, H. Tsikos. Minerals 9, 4692019 (2019).

[51] D. O. B. Jones, J. M. Durden, K. Murphy, K. M. Gjerde, A. Gebicka, A. Colaço, T. Morato, D. Cuvelier, D. S. M. Billett. Mar. Pol. 103, 172 (2019).

[52] D. J. Amon, A. F. Ziegler, T. G. Dahlgren, A. G. Glover, A. Goineau, A. J. Gooday, H. Wiklund, C. R. Smith. Sci. Rep. 6 (2016), https://doi.org/10.1038/srep30492.

[53] C. H. Chuar, S. J. W. Tong, C. K. Chim, H. P. S. Wong, K. S. Tan. Deep-Sea Res. I: Oceanogr. Res. Pap. 161, 103284 (2020).

[54] S. Gollner, S. Kaiser, L. Menzel, D. O. B. Jones, A. Brown, N. C. Mestre, D. van Oevelen, L. Menot, A. Colaço, M. Canals, D. Cuvelier, J. M. Durden, A. Gebruk, G. A. Egho, M. Haeckel, Y. Marcon, L. Mevenkamp, T. Morato, C. K. Pham, A. Purser, A. Sanchez-Vidal, A. Vanreusel, A. Vink, P. M. Arbizu. Mar. Environ. Res. 129, 76 (2017).

[55] GEOMAR. Hekmholtz Centre for Ocean Research, Kiel, Germany (2020).

[56] Y. Moalic, D. Desbruyères, C. M. Duarte, A. F. Rozenfeld, C. Bachraty, S. Arnaud-Haond. Syst. Biol. 61, 127 (2012).

[57] L. Somoza, T. Medialdea, F. J. González, A. Calado, A. Afonso, M. Albuquerque, M. Asensio-Ramos, R. Bettencourt, I. Blasco, J. A. Candón, M. Carreiro-Silva, C. Cid, C. De Ignacio, E. López-Pamo, S. Machancoses, B. Ramos, L. Pinto Ribeiro, B. RincónTomás, E. Santofimia, M. Souto, I. Tojeira, C. Viegas, P. Madureira. Front. Mar. Sci. 7, 568035 (2020).

[58] International Seabed Authority (ISA). ISA Tech. Study Ser. 8, 1 (2011).

[59] M. R. Clark, A. A. Rowden, T. Schlacher, A. Williams, M. Consalvey, K. I. Stocks, A. D. Rogers, T. D. O’Hara, M. White, T. M. Shank, J. M. Hall-Spencer. Ann. Rev. Mar. Sci. 2, 253 (2010).

[60] N. B. Morgan, S. Cairns, H. Reiswig, A. R. Baco. Deep-Sea Res. I: Oceanogr. Res. Pap. 104, 92 (2015).

[61] A. A. Rowden, J. F. Dower, T. A. Schlacher, M. Consalvey, M. R. Clark. Mar. Ecol. 31, 226 (2010).

[62] L. Somoza, J. L. Rueda, O. Sánchez-Guillamón, T. Medialdea, B. Rincón-Tomás, F. J. González \& J.T. Vázquez. Oceans, 2, 351 (2021).

[63] J. R. Hein, A. Koschinsky, T. Kuhn. Nat. Rev. Earth Environ. 1, 158 (2020).

[64] IUCN. Deep-Sea Mining, Gland, Switzerland (2018).

[65] L. Kaikkonen, R. Venesjärvi, H. Nygård, S. Kuikka. Mar. Pollut. Bull. 135, 1183 (2018).

[66] D. V. Ellis. Mar. Georesour. Geotechnol. 19, 51 (2001).

[67] B. Christiansen, A. Denda, S. Christiansen. Mar. Pol. 114 (2020), https://doi.org/10.1016/j.marpol.2019.02.014.

[68] SPC. Deep Sea Minerals: Cobalt-Rich Ferromanganese Crusts, a Physical, Biological, Environmental, and Technical Review, E. Baker, Y. Beaudoin (Eds.), Vol. 1, Secretariat of the Pacific Community, ISBN: 978-82-7701-119-6 (2013).

[69] D. O. B. Jones, J. M. Durden, K. Murphy, K. M. Gjerde, A. Gebicka, A. Colaço, T. Morato, D. Cuvelier, D. S. M. Billett. Mar. Pol. 103, 172 (2019).

[70] A. Vanreusel, A. Hilario, P. A. Ribeiro, L. Menot, P. M. Arbizu. Sci. Rep. 6, 1 (2016). 
[71] ECORYS. Study to Investigate State of Knowledge of deep-sea mining. Final report Annex 6 Environmental analysis FWC MARE/2012/06 - SC E1/2013/04, Rotterdam/Brussels (2014).

[72] M. Allsopp, C. Miller, R. Atkins, S. Rocliffe, I. Tabor, D. Santillo, P. Johnston. Greenpeace Research Laboratories Technical Report (Review), Vol. 3, Exeter, UK (2013).

[73] R. E. Boschen, A. A. Rowden, M. R. Clark, J. P. A. Gardner. Ocean Coast. Manag. 84, 54 (2013).

[74] J. Spearman, J. Taylor, N. Crossouard, A. Cooper, M. Turnbull, A. Manning, M. Lee, B. Murton. Sci. Rep. 10, 5075 (2020).

[75] D. Aleynik, M. E. Inall, A. Dale, A. Vink. Sci. Rep. 7 (2017), https://doi.org/10.1038/s41598-017-16912-2.

[76] DNVGL-RP-0601. Managing Environmental Aspects and Impacts of Seabed Mining. Recommended Practice (2016).

[77] MIDAS. Managing Impacts of Deep Sea Resource Exploitation. Research Highlights, www.eu-midas.net (2020).

[78] M. Navarre, H. Lammens. In Opportunities of Deep-Sea Mining and ESG Risks, P. Blanqué, P. Ithurbide (Eds.), Amundi Discussion Papers Series DP-24-2017, Amundi Asset Management (2017).

[79] M. B. Bashir, S. H. Klim, E. Kiosidou, H. Wolgamot, W. Zhang. The LRET Collegium Series, Vol. 1, ISBN 978-0-854-32949-6 (2012).

[80] E. E. Cordes, D. O. Jones, T. A. Schlacher, D. J. Amon, A. F. Bernardino, S. Brooke, R. Carney, D. M. DeLeo, K. M. Dunlop, E. G. Escobar-Briones, A. R. Gates, L. Génio, J. Gobin, L. A. Henry, S. Herrera, S. Hoyt, S. Joye, S. Kark, N. C. Mestre, A. Metaxas, S. Pfeifer, K. Sink, A. K. Sweetman, U. F. Witte. Front. Environ. Sci. 4, 58 (2016).

[81] J. M. Markussen. In Deep Seabed Mining and the Environment: Consequences, Perceptions, and Regulations, H. O. Bergesen, G. Parmann (Eds.), pp. 31-39, Green Globe Yearbook of International Co-operation on Environment and Development. Oxford: Oxford University Press (1994).

[82] L. Heinrich, A. Koschinsky, T. Markus, P. Singh. Mar. Pol. 114, 103678 (2020).

[83] C. L. Van Dover, J. Aronson, L. Pendleton, S. Smith, S. Arnaud-Haond, D. Moremo-Mateos, E. Barbier, D. Billet, K. Bowers, R. Danovaro, E. Edwards, S. Kellert, T. Morato, E. Pollard, A. Rogers, R. Warner. Mar. Pol. 44, 98 (2014).

[84] P. C. Collins, R. Kennedy, C. L. Van Dover. Mar. Ecol: Prog. Ser. 452, 89 (2012).

[85] C. L. Van Dover. Mar. Environ. Res. 102, 59 (2014).

[86] C. L. Van Dover, J. A. Ardron, E. Escobar, M. Gianni, K. M. Gjerde, A. Jaeckel, D. O. B. Jones, L. A. Levin, H. J. Niner, L. Pendleton, C. R. Smith, T. Thiele, L. Pendleton, P. J. Turner, L. Watling, P. P. E. Weaver. Nat. Geosci. 10, 464 (2017).

[87] International Seabed Authority. ISA Tech. Study Ser. 10, 1 (2012).

[88] C. L. Van Dover, S. Arnaud-Haond, M. Gianni, S. Helmreich, J. A. Huber, A. L. Jaeckel, A. Metaxas, L. H. Pendleton, S. Petersen, E. Ramirez-Llodra, P. E. Steinberg, V. Tunnicliffe, H. Yamamoto. Mar. Pol. 90, 20 (2018).

[89] D. O. B. Jones, J. A. Ardron, A. Colaço, J. M. Durden. Mar. Pol. 10 (2018).

[90] T. Kuhn, A. Wegorzewski, C. Rühlemann, A. Vink. In Deep-Sea Mining: Resource Potential, Technical and Environmental Considerations, R. Sharma (Ed.), pp. 23-64, Springer International, Cham (2017).

[91] M. G. Petterson, A. Tawake. Ocean Coast. Manag. 167, 271 (2019).

[92] S. J. Pak, I. Seo, K. Y. Lee, K. Hyeong. Minerals 9, 3 (2019).

[93] J. R. Hein. Prospects for Rare Earth Elements from Marine Minerals. Briefing Paper 02/12, International Seabed Authority, New York (2012).

[94] J. Milinovic, F. J. L. Rodrigues, F. J. A. S. Barriga, B. J. Murton. Minerals 11, 142 (2021).

[95] European Commission. Blue Growth. European Commission. COM, p. 494 (2012), final, https://ec.europa.eu/ maritimeaffairs/documentation/publications/documents/blue-growth_en.pdf.

[96] EMODnet-Geolog (2021).

[97] AORA (2021).

[98] Blue Mining (2021).

[99] Blue Nodules (2021).

[100] Marine E-Tech (2021).

[101] GeoERA. Establishing the European Geological Surveys Research Area to deliver a Geological Service for Europe, Netherlands, https://geoera.eu/ (2020).

[102] MINDESEA (2021).

\section{Relevant-related projects}

Blue Nodules; https://blue-nodules.eu/. Blue Mining; https://bluemining.eu/. DISCOL; https://www.discol.de/. JPI Oceans; https://www.jpi-oceans.eu/. MIDAS; https://www.eu-midas.net/. MINDeSEA; https://geoera.eu/projects/mindesea2/. 